\title{
Influence of climate warming and nitrogen deposition on soil phosphorus composition and phosphorus availability in a temperate grassland, China
}

\author{
GuangNa ZHANG ${ }^{1,2,3}$, ZhenHua CHEN ${ }^{1}$, AiMing ZHANG ${ }^{1,2}$, LiJun $\mathrm{CHEN}^{1 *}$, ZhiJie $\mathrm{WU}^{4}$ \\ ${ }^{1}$ State Key Laboratory of Forest and Soil Ecology, Institute of Applied Ecology, Chinese Academy of Sciences, Shenyang \\ 110164, China; \\ ${ }^{2}$ University of Chinese Academy of Sciences, Beijing 100049, China; \\ ${ }^{3}$ Shandong Provincial Key Laboratory of Water and Soil Conservation \& Environmental Protection, Linyi University, Linyi \\ 276000, China; \\ ${ }^{4}$ Institute of Applied Ecology, Chinese Academy of Sciences, Shenyang 110016, China
}

\begin{abstract}
Climate warming and nitrogen $(\mathrm{N})$ deposition change ecosystem processes, structure, and functioning whereas the phosphorus $(P)$ composition and availability directly influence the ecosystem structure under conditions of $\mathrm{N}$ deposition. In our study, four treatments were designed, including a control, diurnal warming (DW), $\mathrm{N}$ deposition (ND), and combined warming and $\mathrm{N}$ deposition (WN). The effects of DW, ND, and WN on P composition were studied by ${ }^{31} \mathrm{P}$ nuclear magnetic resonance $\left({ }^{31} \mathrm{P} N \mathrm{NM}\right)$ spectroscopy in a temperate grassland region of China. The results showed that the $\mathrm{N}$ deposition decreased the soil $\mathrm{pH}$ and total $\mathrm{N}(\mathrm{TN})$ concentration but increased the soil Olsen-P concentration. The solution-state ${ }^{31} \mathrm{P}$ NMR analysis showed that the DW, ND and WN treatments slightly decreased the proportion of orthophosphate and increased that of the monoesters. An absence of myo-inositol phosphate in the DW, ND and WN treatments was observed compared with the control. Furthermore, the DW, ND and WN treatments significantly decreased the recovery of soil $\mathrm{P}$ in the $\mathrm{NaOH}$-EDTA solution by $17 \%-20 \%$. The principal component analysis found that the soil $\mathrm{pH}$ was positively correlated with the $\mathrm{P}$ recovery in the $\mathrm{NaOH}-\mathrm{EDTA}$ solution. Therefore, the decreased soil $\mathrm{P}$ recovery in the DW and ND treatments might be caused by an indirect influence on the soil pH. Additionally, the soil moisture content was the key factor limiting the available $\mathrm{P}$. The positive correlation of total carbon (TC) and TN with the soil $\mathrm{P}$ composition indicated the influence of climate warming and $\mathrm{N}$ deposition on the biological processes in the soil $\mathrm{P}$ cycling.
\end{abstract}

Keywords: climate warming; nitrogen deposition; temperate grassland; ${ }^{31} \mathrm{P}$ nuclear magnetic resonance spectroscopy

Citation: GuangNa ZHANG, ZhenHua CHEN, AiMing ZHANG, LiJun CHEN, ZhiJie WU. 2014. Influence of climate warming and nitrogen deposition on soil phosphorus composition and phosphorus availability in a temperate grassland, China. Journal of Arid Land, 6(2): 156-163. doi: 10.1007/s40333-013-0241-4

Soil phosphorous (P) composition provides important information for grassland ecosystems, especially because $\mathrm{P}$ is often the growth-limiting nutrient when nitrogen (N) is not limited (Jouany et al., 2011). The soil organic phosphorus $\left(\mathrm{P}_{\mathrm{o}}\right)$ can constitute $20 \%$ to $80 \%$ of the total phosphorus (TP) in the soil (Dalal, 1977; Dai et al., 1996). Although large concentrations of $\mathrm{P}_{\mathrm{o}}$ persist in soils (Hawkes et al., 1984; Turner et al., 2003a, b), its potential availability is determined by the type of soil P compounds (Turner et al., 2004), which suggests that a greater soil concentration of diesters could provide readily available $\mathrm{P}$ whereas a greater concentration of monoesters only provides with potentially available P. For example, orthophosphate diesters can be degraded in soil in a short time, whereas phytate is more stable and is difficult to min-

*Corresponding author: LiJun CHEN (E-mail: 1jchen@iae.ac.cn) Received 2012-12-27; revised 2013-04-27; accepted 2013-06-06

(C) Xinjiang Institute of Ecology and Geography, Chinese Academy of Sciences, Science Press and Springer-Verlag Berlin Heidelberg 2014 
eralize due to the low phytase activity in soil (Bowman and Cole, 1978). The soil P bioavailability in grassland ecosystems could be influenced by climate warming and $\mathrm{N}$ deposition because the $\mathrm{P}$ cycle is controlled by biochemical and biological processes (McGill and Cole, 1981).

Climate warming has caused an average global temperature increase of $0.74^{\circ} \mathrm{C}$ in the past 100 years (IPCC, 2007), and some studies have reported that this has led to an increase in the decomposition rate of soil organic carbon (Kirschbaum, 2000; Davidson and Janssens, 2006). Consequently, these biological processes could release more available inorganic $\mathrm{P}\left(\mathrm{P}_{\mathrm{i}}\right)$ in soils. In addition to the effect on $\mathrm{P}$ mineralization, elevated temperatures were reported to affect the soil $\mathrm{P}$ composition by decreasing the amount of monoester-P (Sumann et al., 1998). N deposition could also affect both the biological and biochemical mineralization of soil P. For example, $\mathrm{N}$ deposition was reported to increase the labile carbon mineralization via biological processes (Currey et al., 2010) and increase the biological $\mathrm{P}$ limitation via biochemical processes (Turner et al., 2003a; Hogan et al., 2010), which might influence the composition and availability of $\mathrm{P}$. In addition, the availability of $\mathrm{P}$ was reported to play an important role in regulating species diversity under conditions of $\mathrm{N}$ deposition (Limpens et al., 2004). The single factor of either warming or $\mathrm{N}$ deposition might influence the soil $\mathrm{P}$ composition and availability, thus the combination of both was also considered as a manipulated factor.

To investigate the influence of climate warming and $\mathrm{N}$ deposition on ecosystem processes, structure, and functioning, Niu and Wan (2008) established a field trial in Inner Mongolia of China in 2006 and found that warming significantly increased the soil temperature by $1.9^{\circ} \mathrm{C}$ and suppressed the competitive ability of a $\mathrm{C}_{4}$ grass while increasing that of a $\mathrm{C}_{3}$ forb and a $\mathrm{C}_{3}$ grass. The effect of warming on carbon $(\mathrm{C})$ sequestration was insignificant whereas the $\mathrm{N}$ deposition stimulated the exchange of $\mathrm{C}$ in the ecosystem by increasing the $\mathrm{C}$ assimilation process during the wet growing season (Xia et al., 2009).

The effects of warming and $\mathrm{N}$ deposition on $\mathrm{N}$ use efficiency, $\mathrm{C}$ sequestration, and species diversity were extensively studied (An et al., 2005; Niu and Wan, 2008; Xia et al., 2009), but little information can be found about the soil $\mathrm{P}$ composition and $\mathrm{P}$ availability in temperate grassland soils under the condition of warming, $\mathrm{N}$ deposition and their combination. We hypothesize that climate warming, $\mathrm{N}$ deposition or their combination would influence soil $\mathrm{P}$ availability (Olsen-P) and soil $\mathrm{P}$ composition by changing the concentrations of different $\mathrm{P}$ fractions such as phosphonates, orthophosphates, orthophosphate monoesters, orthophosphate diesters, pyrophosphates and polyphosphates.

\section{Materials and methods}

\subsection{Study area}

The study area is located in Duolun county, Inner Mongolia, China $\left(42^{\circ} 20^{\prime} \mathrm{N}, 116^{\circ} 17^{\prime} \mathrm{E} ; 1,324 \mathrm{~m}\right.$ asl). The mean annual precipitation is $385 \mathrm{~mm}$, with $86 \%$ of the rainfall occurring from May to September. The annual mean temperature is $2.1^{\circ} \mathrm{C}$, with monthly averages ranging from $-17.5^{\circ} \mathrm{C}$ in January to $18.9^{\circ} \mathrm{C}$ in July. The soil is classified as Haplic Calcisol according to the Food and Agricultural Organization of the United Nations (FAO classification), with $63 \%$ sand, $20 \%$ silt, and $17 \%$ clay (Niu and Wan, 2008). The flora was consistent throughout the area and was dominated by Stipa krylovii, Artemisia frigida, Potentilla acaulis, Cleistogenes squarrosa, Allium bidentatum, and Agropyron cristatum. The study area has been overgrazed since the 1980s and has experienced severe soil degradation and nutrient loss. The field was fenced in 2001 to prohibit grazing for ecological restoration.

\subsection{Experimental design}

Four treatments were conducted in this study: a control, diurnal (24-h) warming (DW), $\mathrm{N}$ deposition (ND), and diurnal warming with $\mathrm{N}$ deposition $(\mathrm{WN})$. Each treatment was replicated in six $3 \mathrm{~m} \times 4 \mathrm{~m}$ plots according to a complete random block design. Three-meter buffer zones separated each plot. The plots were warmed using MSR-2420 infrared radiators (Kalglo Electronics, Bethlehem, Pennsylvania, USA) hung at a height of $2.25 \mathrm{~m}$ and set to $1,600 \mathrm{~W}$. Inactivated "dummy" heaters (i.e. non-functional heaters identical to the one used 
to treat the 'warming' plots) were installed over the control plots to duplicate the shading effect. The experimental plots were established in September 2005 and the simulated warming experiment was initiated on 23 April 2006. The heaters were kept off from 15 November 2007 to 14 March 2008 and from 1 December 2008 to 1 March 2009 because the station was closed during deep winters. For the ND treatment, urea (10 g $\mathrm{N} / \mathrm{m}^{2}$ ) was applied for the first year in September 2006, and $\mathrm{NH}_{4} \mathrm{NO}_{3}\left(10 \mathrm{~g} \mathrm{~N} / \mathrm{m}^{2}\right)$ was applied instead of urea on 19 July during the following years.

\subsection{Soil properties and sampling}

In August 2009, soil cores were sampled at a depth of $15 \mathrm{~cm}$; each sample was composed of three cores per plot. The fresh samples were sieved $(<2 \mathrm{~mm})$ and preserved in a refrigerator at $4{ }^{\circ} \mathrm{C}$. The subsamples were air-dried at ambient temperature for at least one week and were stored prior to the chemical analysis.

The soil water content was measured gravimetrically after drying at $105^{\circ} \mathrm{C}$ for $24 \mathrm{~h}$. The soil $\mathrm{pH}$ was measured using a glass electrode (soil/water ratio of 1.0:2.5). The total carbon (TC) and total nitrogen (TN) were determined using an automatic element analyzer (Vario EL, Elementar, Germany). The Olsen P was extracted using $0.5 \mathrm{M} \mathrm{NaHCO}_{3}$ at a pH of 8.5 (Olsen et al., 1954); the $\mathrm{P}$ in the filtrate was then determined colorimetrically by the molybdate method (Murphy and Riley, 1962). TP was digested from $2.0 \mathrm{~g}$ of the air-dried soil $(<0.15 \mathrm{~mm})$ in $30 \mathrm{~mL}$ of $70 \%$ perchloric acid, and the $\mathrm{P}$ was measured colorimetrically (Kuo, 1996).

\subsection{Soil $P$ composition with solution-state ${ }^{31} P$ NMR spectroscopy}

The soil P composition was determined using solution-state ${ }^{31} \mathrm{P}$ NMR spectroscopy. Briefly, the air-dried soil $(<2 \mathrm{~mm}, 2.5 \mathrm{~g})$ was shaken in $50 \mathrm{~mL}$ of a $0.25 \mathrm{M}$ $\mathrm{NaOH}-0.05 \mathrm{M} \mathrm{Na}_{2}$ EDTA solution at $20^{\circ} \mathrm{C}$ for $16 \mathrm{~h}$. The extracts were centrifuged at $10,000 \mathrm{~g}$ for $30 \mathrm{~min}$, and $20 \mathrm{~mL}$ aliquots from the six replicates were combined into a composite extract for each treatment, and the composite extracts were then frozen and lyophilized. The total $\mathrm{P}$ in solution was determined using inductively coupled plasma-optical emission spectroscopy (ICP-OES; PE OPTIMA 3000). The P re- covery was calculated by comparing the TP in the $\mathrm{NaOH}-\mathrm{EDTA}$ extracts with the soil TP.

Approximately $200 \mathrm{mg}$ of the freeze-dried extracts were redissolved in $0.1 \mathrm{~mL}$ of $10 \mathrm{M} \mathrm{NaOH}$ and 0.5 $\mathrm{mL}_{2} \mathrm{O}$ and then decanted into 5-mm NMR tubes. The solution-state ${ }^{31} \mathrm{P}$ NMR spectra were acquired at $24^{\circ} \mathrm{C}$ using a JEOL ECA 600 spectrometer operating at $243 \mathrm{MHz}$ with a $45^{\circ}$ pulse width (5.2 $\mu$ s pulse), an acquisition time of $0.77 \mathrm{~s}\left(50 \times 10^{-6}\right.$ window centered at $0 \times 10^{-6}$ ), a delay time of $1.0 \mathrm{~s}$, broadband proton decoupling, and 26,000 scans. The chemical shifts were determined in relation to external $85 \% \mathrm{H}_{3} \mathrm{PO}_{4}$ (at $\delta=0)$. All of the spectral results were processed with the NMR Utility Transform Software (NUTS) for Windows (Acorn NMR, Livermore, CA), and the peaks were assigned by referring to the literature (Turner et al., 2003c; Turner, 2007; Zhang et al., 2012). The amounts of the different forms of $\mathrm{P}$ were calculated by multiplying the percentage of the integrated area of each assigned peak to the total integration area by the TP extracted with $\mathrm{NaOH}-\mathrm{EDTA}$.

\subsection{Statistical analyses}

The results were presented as the mean $\pm \mathrm{SE}$ (standard error, $n=6)$. The differences among the treatments were tested using the one-way ANOVA in SPSS 11.5 for Windows (SPSS Inc., Chicago, IL). After determining that the within-group variance was equal across the groups associated with each mean, Tukey's method was used to perform a mean separation test and was considered significant at a $5 \%$ level $(P<0.05)$. A detrended correspondence analysis was applied to determine the lengths of the $\mathrm{P}$ composition gradients and the soil properties, which showed that the lengths of the gradients were less than 3. A principal components analysis (PCA) was then applied to identify the effects of climate warming and $\mathrm{N}$ deposition on the soil properties, $\mathrm{P}$ recovery and $\mathrm{P}$ composition using Canoco Software 4.5 (Microcomputer Power, USA).

\section{Results}

\subsection{Soil properties}

The soil $\mathrm{pH}$ values ranged from 6.7 to 7.3 and decreased significantly under the treatments with $\mathrm{N}$ deposition (ND and $\mathrm{WN}$ ) after 5 years of $\mathrm{N}$ applica- 
tion (Table 1). The TC concentrations were not affected by warming and $\mathrm{N}$ deposition. The ND treatment significantly decreased the soil TN compared with the control, and no differences in soil TP were found among the treatments. The Olsen-P concentration ranged from 14.4 to $23.6 \mathrm{mg} / \mathrm{kg}$ soil, with the highest value found for the ND treatment. The tested soils had low soil moisture contents, with even the fresh samples containing only $5.7 \%-6.5 \%$ water, and no significant differences among treatments were found (Table 1).

\subsection{Soil $P$ composition}

The solution-state ${ }^{31} \mathrm{P}$ NMR spectra with $10 \mathrm{~Hz}$ line broadening are shown in Fig. 1. The strong signals at approximately $6.7 \times 10^{-6}$ were assigned to inorganic orthophosphate, with concentrations ranging from 32 to $50 \mathrm{mg} \mathrm{P} / \mathrm{kg}$ soil (Table 2). Pyrophosphate was identified at approximately $-3.1 \times 10^{-6}$, ranging from 2.8 to $5.2 \mathrm{mg} \mathrm{P} / \mathrm{kg}$ soil (Table 2 ).
The orthophosphate monoesters were dominant in every treatment, ranging from 104 to $139 \mathrm{mg} \mathrm{P} / \mathrm{kg}$ soil ( $72 \%-75 \%$ of extracted P). Only the control showed the myo-inositol hexakisphosphate signal with a distinct $\mathrm{C}-2$ position at $6.0 \times 10^{-6}$ at a concentration of 11 $\mathrm{mg} \mathrm{P} / \mathrm{kg}$ soil (Table 2). The signal for scyllo-inositol hexakisphosphate can be identified at approximately $4.1 \times 10^{-6}$, with concentrations ranging from 5.5 to 7.5 $\mathrm{mg} \mathrm{P} / \mathrm{kg}$ soil. No orthophosphate diesters, such as DNA or phospholipids, were found in this study (Table 2).

Warming and $\mathrm{N}$ deposition markedly decreased the $\mathrm{P}$ recovery, slightly decreased the content of soil orthophosphate and increased that of monoesters.

\subsection{The PCA of soil properties and $P$ composition}

The results of the PCA indicated that Factors 1 and 2 accounted for $82.8 \%$ and $14.3 \%$ of the total variance, respectively (Fig. 2). Factor 1 was related to the soil moisture content and Factor 2 was related to the soil

Table $1 \mathrm{pH}, \mathrm{TC}, \mathrm{TN}, \mathrm{TP}$, Olsen-P and moisture content for soils treated for 4 years with four different treatments

\begin{tabular}{|c|c|c|c|c|c|c|}
\hline \multirow{2}{*}{ Treatment } & \multirow{2}{*}{$\mathrm{pH}$} & $\mathrm{TC}$ & $\mathrm{TN}$ & $\mathrm{TP}$ & Olsen-P & \multirow{2}{*}{ Moisture content $(\%)$} \\
\hline & & \multicolumn{4}{|c|}{$\mathrm{g} / \mathrm{kg}$} & \\
\hline Control & $7.2 \pm 0.03 \mathrm{a}$ & $24.9 \pm 1.15 \mathrm{a}$ & $2.01 \pm 0.09 \mathrm{a}$ & $335 \pm 19 a$ & $16.3 \pm 1.8 \mathrm{~b}$ & $6.5 \pm 0.59 a$ \\
\hline DW & $7.3 \pm 0.05 \mathrm{a}$ & $24.0 \pm 1.12 \mathrm{a}$ & $1.82 \pm 0.07 \mathrm{a}$ & $335 \pm 7.2 \mathrm{a}$ & $17.4 \pm 1.2 b$ & $5.7 \pm 0.43 a$ \\
\hline ND & $6.7 \pm 0.07 \mathrm{~b}$ & $22.6 \pm 1.04 \mathrm{a}$ & $1.70 \pm 0.09 \mathrm{~b}$ & $373 \pm 23 a$ & $23.6 \pm 3.2 \mathrm{a}$ & $5.7 \pm 0.23 \mathrm{a}$ \\
\hline $\mathrm{WN}$ & $6.7 \pm 0.05 b$ & $22.8 \pm 0.74 a$ & $1.77 \pm 0.04 b$ & $310 \pm 23 a$ & $14.4 \pm 1.1 \mathrm{~b}$ & $5.8 \pm 0.59 a$ \\
\hline
\end{tabular}

Note: DW, diurnal warming; ND, N deposition; WN, diurnal warming with $\mathrm{N}$ deposition. Results were presented as mean \pm standard error. Values within one column with the same letter are not significant at $5 \%$ level.

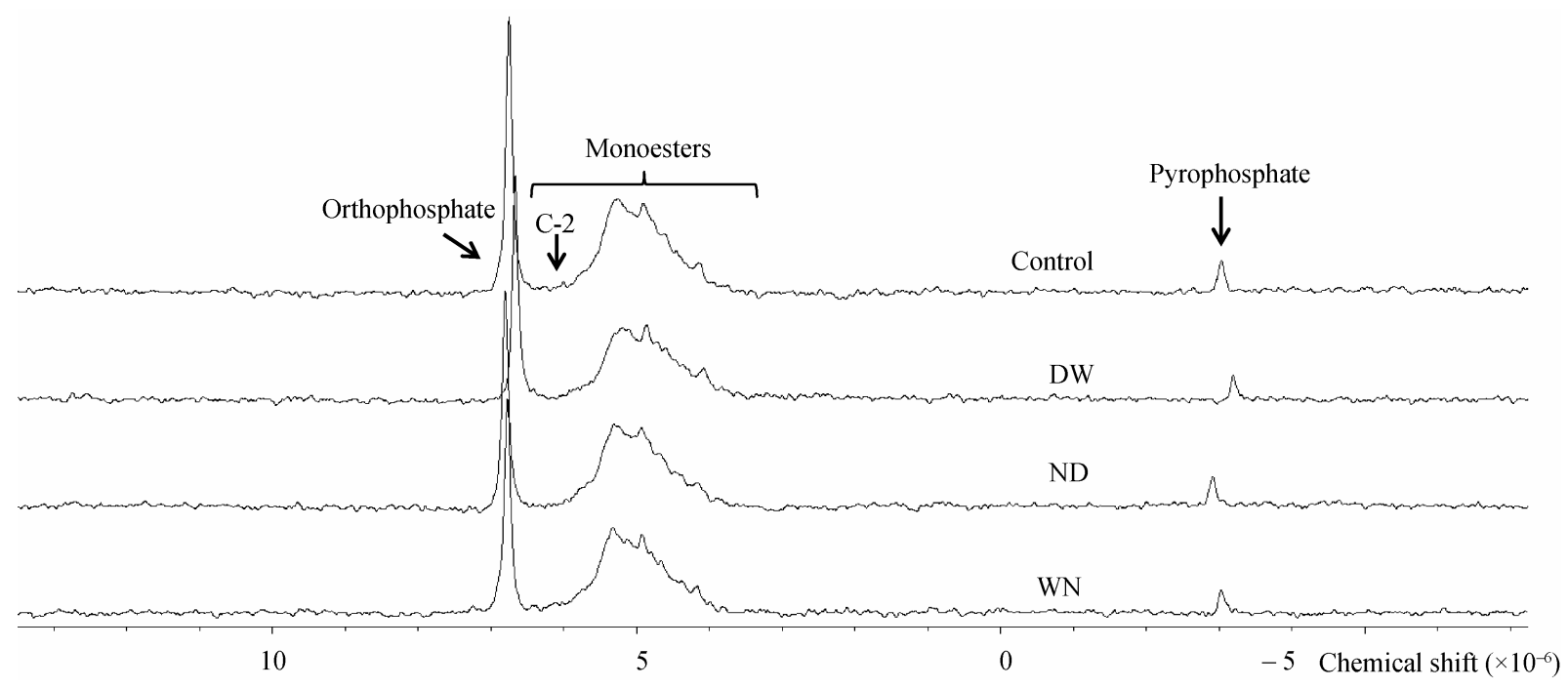

Fig. 1 Solution ${ }^{31} \mathrm{P}$ NMR spectra of $\mathrm{NaOH}-\mathrm{EDTA}$ of soil extracts in a temperate grassland, China 
Table 2 Soil phosphorus concentration (mg P/kg soil) in NaOH-EDTA extracts determined by solution ${ }^{31} \mathrm{P}$ NMR spectroscopy

\begin{tabular}{|c|c|c|c|c|c|c|}
\hline \multirow{3}{*}{ Treatment } & \multirow{3}{*}{ Total $\mathrm{P}^{*}$} & \multicolumn{2}{|c|}{ Inorganic $\mathrm{P}$} & \multirow{2}{*}{\multicolumn{3}{|c|}{$\frac{\text { Organic } \mathrm{P}}{\text { Orthophosphate monoesters }}$}} \\
\hline & & \multirow[t]{2}{*}{ Orthophosphate } & \multirow[t]{2}{*}{ Pyrophosphate } & & & \\
\hline & & & & $\begin{array}{l}\text { Total mono- } \\
\text { esters }\end{array}$ & $\begin{array}{l}\text { myo-inositol hexakisphos- } \\
\text { phate }\end{array}$ & $\begin{array}{l}\text { scyllo-inositol hexakisphos- } \\
\text { phate }\end{array}$ \\
\hline Control & $\begin{array}{l}194 \\
(58)\end{array}$ & $50(26 \%)$ & $5.2(2.7 \%)$ & $139(72 \%)$ & $11(5.9 \%)$ & $6.9(3.6 \%)$ \\
\hline DW & $\begin{array}{l}140 \\
(41)\end{array}$ & $32(23 \%)$ & $2.8(2.0 \%)$ & $104(75 \%)$ & nd & $7.5(5.3 \%)$ \\
\hline ND & $\begin{array}{l}141 \\
(38)\end{array}$ & $32(23 \%)$ & $4.5(3.2 \%)$ & $104(74 \%)$ & nd & $5.5(3.9 \%)$ \\
\hline WN & $\begin{array}{l}143 \\
(47)\end{array}$ & $33(23 \%)$ & $3.0(2.1 \%)$ & $106(74 \%)$ & nd & $6.0(4.2 \%)$ \\
\hline
\end{tabular}

Note: DW, diurnal warming; ND, $\mathrm{N}$ deposition; WN, diurnal warming with $\mathrm{N}$ deposition. nd, not detected; values in parentheses indicate the percentage of the total extracted P; ${ }^{*}$ indicates the values in parentheses stand for recovery of extracted TP from soil TP.

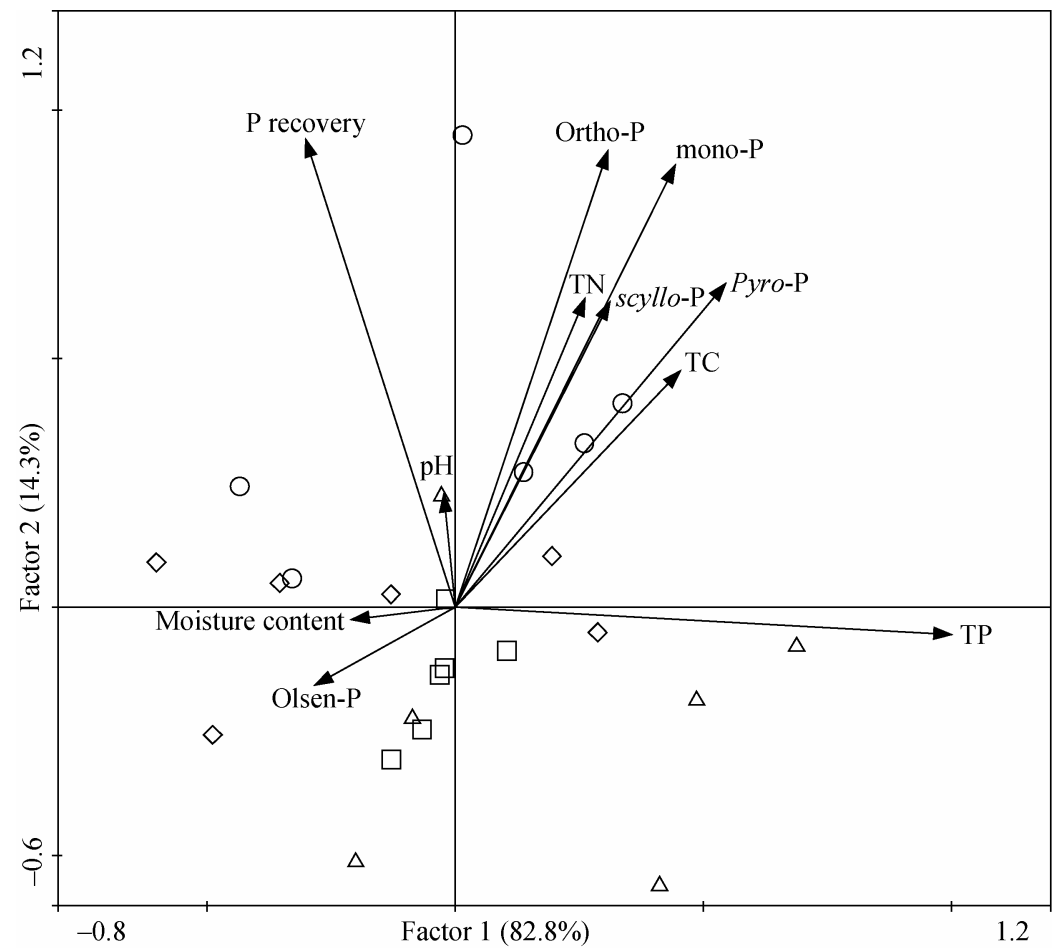

Fig. 2 Principal components analysis (PCA) of soil moisture content, pH, total carbon (TC), total nitrogen (TN), total phosphorus (TP), Olsen-P, orthophosphate (Ortho-P), monoesters (mono-P), scyllo-inositol hexaphosphate (scyllo-P), and pyrophosphate (pyro-P) for soils treated for 4 years with 1) control (०); 2) diurnal (24-h) warming (DW, 口); 3) nitrogen deposition (ND, $\triangle$ ); 4) diurnal (24-h) warming with $N$ deposition $(\mathrm{WN}, \diamond)$.

$\mathrm{pH}$. Specifically, the soil $\mathrm{P}$ composition and the P recovery in the $\mathrm{NaOH}-\mathrm{EDTA}$ extract increased with the soil $\mathrm{pH}$, which could be influenced by the $\mathrm{N}$ deposition. The soil Olsen-P concentration was positively correlated with the soil moisture content. The results also showed that the soil TC and TN were positively correlated with the soil $\mathrm{P}$ composition, which included orthophosphate, monoesters, pyrophosphates and scyllo-inositol hexaphosphate.

\section{Discussion}

\subsection{Soil properties}

The results of the one-way ANOVA showed that soil $\mathrm{pH}$ (sampled to a $15-\mathrm{cm}$ depth) decreased due to the acidification resulting from $\mathrm{N}$ fertilization $(P<0.05)$, which has been extensively reported (Guo et al., 2010; Li et al., 2010; Malhi et al., 2011) and regarded to be 
connected with the release of $\mathrm{H}^{+}$ions during the nitrification process (Bolan et al., 1991). This study determined that $\mathrm{N}$ addition had no effect on $\mathrm{TC}$, which was similar to the findings of another report regarding the TC change in a semi-arid grassland ( $\mathrm{Li}$ et al., 2010). In comparison with our study, many researchers have reported an increase in the TC concentration with soil fertilization. For example, Nyborg et al. (1999) showed that 13 years of $\mathrm{N}$ and sulfur fertilization increased the soil TC. Tiemann and Billings (2011) found that after 7 years of $\mathrm{N}$ fertilization, the TC concentrations were higher than those in unfertilized plots. The reason for this discrepancy could be that, in this study, the decomposition rate of TC was nearly the same as the accumulation rate of TC in the semi-arid grassland after the addition of $\mathrm{N}$. The soil $\mathrm{TN}$ decreased under the ND and WN treatments $(P<0.05)$, which could be attributed to the enhanced plant uptake of $\mathrm{N}$ from the soil by the stimulation from $\mathrm{N}$ fertilization (Xia et al., 2009). The higher Olsen-P concentration under the ND treatment could be caused by higher $\mathrm{P}$ concentration from dead microbes in the air-dried samples (Turner and Haygarth, 2001), as the soil microbial biomass could increase with the addition of $\mathrm{N}$ (Johnson et al., 1998). It is also possible that the decreased soil $\mathrm{pH}$ under $\mathrm{N}$ addition resulted in fewer exchangeable cations and thus decreased the sorption of soil P to cations (Zhang et al., 2013). The PCA showed that the soil moisture content was positively correlated with the Olsen-P concentration, which indicated that the exchangeable $\mathrm{P}$ (Olsen-P) was more influenced whereas the adsorbed $\mathrm{P}$ (other $\mathrm{P}$ fractions) was less influenced by the soil moisture.

\subsection{Soil P composition}

The orthophosphate monoesters were the dominant $\mathrm{P}$ fraction in this study $(72 \%-75 \%$ of the total extracted $\mathrm{P})$, which is in agreement with previous studies on grassland soils (McDowell et al., 2005; Murphy et al., 2009). Under the warming and $\mathrm{N}$ deposition treatments, the proportion of monoesters increased while the proportion of orthophosphate decreased. In contrast with our study, Sumann (1998) reported that the proportion of monoesters decreased due to higher microbial activities at cooler temperatures. In addition,
Turner et al. (2003a) reported an increase in the orthophosphate proportion under $\mathrm{N}$ deposition conditions. These different results could be attributed to the soil moisture content, which was reported to influence microbial activities and phosphatase activities (Donnelly et al., 1990; Turner and Romero, 2010). A greater percentage of orthophosphate monoesters suggests lower environmental risks under warming and $\mathrm{N}$ deposition treatments, as the monoesters are easily adsorbed by soil cations and thus decrease the mobility in soil (Celi and Barberis, 2007). No orthophosphate diesters were found in this study, which could be due to the neutral $\mathrm{pH}$ and the drier condition of the soils. It has been shown that soil diesters such as DNA accumulate in acidic soils with soil $\mathrm{pH}$ less than 5 (Turner and Engelbrecht, 2011). Furthermore, moist soils contain higher concentrations of diesters than drier soils (Guggenberger et al., 1996; Sumann et al., 1998). The positive relationship of TC and TN with soil $\mathrm{P}$ fractions indicated that the biological process primarily influenced soil $\mathrm{P}$ composition under warming and $\mathrm{N}$ deposition treatments. Furthermore, the acid phosphatase, alkaline phosphatase and phosphodiesterase activities in the soil were not affected by warming and $\mathrm{N}$ deposition (data not shown), ruling out the biochemical influences of warming and $\mathrm{N}$ deposition. The positive effect of the ND treatment on $\mathrm{P}$ availability showed no biological $\mathrm{P}$ limitations in this area.

Generally, the control contained more orthophosphate and monoesters than the other three treatments, and this result was due to the difference in the total $\mathrm{P}$ recovery rate in the $\mathrm{NaOH}-\mathrm{EDTA}$ solution. There are few reports about the differences in $\mathrm{P}$ recovery caused by management methods such as $\mathrm{N}$ deposition and environmental warming. Turner et al. (2003b) showed that the $\mathrm{P}$ recovery in the $\mathrm{NaOH}-\mathrm{EDTA}$ solution could increase in a warm and moist climate; however, it could be reduced in semi-arid or arid areas (Turner et al., 2003d). This study indicates that warming, $\mathrm{N}$ deposition and their interactions decreased soil $\mathrm{P}$ recovery by $17 \%-20 \%$. The PCA indicated that this may result from the indirect effects of the DW, ND and $\mathrm{WN}$ treatments on soil $\mathrm{pH}$. 


\section{Conclusion}

Warming and $\mathrm{N}$ addition could indirectly influence the soil $\mathrm{P}$ recovery in $\mathrm{NaOH}-\mathrm{EDTA}$ solution and the soil $\mathrm{P}$ composition by changing the soil $\mathrm{pH}$ and soil moisture content. The recovery of soil $\mathrm{P}$ markedly decreased (17\%-20\%) under the DW, ND and WN treatments compared with the control. The solution-state ${ }^{31} \mathrm{P}$ NMR spectroscopy analysis showed that the $\mathrm{P}$ composition in the NaOH-EDTA extracts was dominated by phosphomonoesters $(72 \%-75 \%)$, followed by orthophosphate $(23 \%-26 \%)$, and contained small amounts of pyrophosphate. Scyllo-inositol hexakisphosphate was found in all treatments, whereas only the control treatment contained myo-inositol hexakisphosphate. Apart from soil $\mathrm{pH}$, the effect of warming and $\mathrm{N}$ deposition on soil moisture had an important influence on soil $\mathrm{P}$ composition. Therefore, further research should be conducted regarding the long-term effect of warming, $\mathrm{N}$ deposition and other environmental factors such as water stress on soil $\mathrm{P}$ availability and myo-inositol hexakisphosphate.

\section{Acknowledgements}

This study was supported by the National Natural Science Foundation of China (41171241) and the National Basic Research Program of China (2011CB403204). The authors thank Prof. ShiQiang WAN and Dr. JianYang XIA at the Institute of Botany, Chinese Academy of Sciences, for their field and laboratory assistance. HaiJun YANG from the Department of Chemistry, Tsinghua University, China is also appreciated for the ${ }^{31}$ P NMR spectroscopy analysis.

\section{References}

An Y, Wan S Q, Zhou X H, et al. 2005. Plant nitrogen concentration, use efficiency, and contents in a tallgrass prairie ecosystem under experimental warming. Global Change Biology, 11(10): 1733-1744.

Bolan N S, Hedley M L, White R E. 1991. Processes of soil acidification during nitrogen cycling with emphasis on legume based pastures. Plant and Soil, 134(1): 53-63.

Bowman R A, Cole C V. 1978. Transformations of organic phosphorus substrates in soils as evaluated by $\mathrm{NaHCO}_{3}$ extraction. Soil Science, 125(1): 49-54.

Celi L, Barberis E. 2007. Abiotic reactions of inositol phosphates in soil. In: Turner B L, Richardson A E, Mullaney E J. Inositol Phosphates: Linking Agriculture and the Environment. Wallingford: CAB In- ternational, 207-220.

Currey P M, Johnson D, Sheppard L J, et al. 2010. Turnover of labile and recalcitrant soil carbon differ in response to nitrate and ammonium deposition in an ombrotrophic peatland. Global Change Biology, 16(8): 2307-2321.

Dai K H, David M B, Vance G F, et al. 1996. Characterization of phosphorus in a spruce-fir Spodosol by phosphorus-31 nuclear magnetic resonance spectroscopy. Soil Science Society of America Journal, 60(6): 1943-1950.

Dalal R C. 1977. Soil organic phosphorus. Advances in Agronomy, 29: 83-117.

Davidson E A, Janssens I A. 2006. Temperature sensitivity of soil carbon decomposition and feedbacks to climate change. Nature, 440(7081): 165-173.

Donnelly P K, Entry J A, Crawford D L, et al. 1990. Cellulose and lignin degradation in forest soils: response to moisture, temperature, and acidity. Microbial Ecology, 20(1): 289-295.

Guggenberger G, Christensen B T, Rubwk G, et al. 1996. Land-use and fertilization effects on $\mathrm{P}$ forms in two European soils: resin extraction and ${ }^{31} \mathrm{P}-\mathrm{NMR}$ analysis. European Journal of Soil Science, 47: 605-614.

Guo J, Liu X, Zhang Y, et al. 2010. Significant acidification in major Chinese croplands. Science, 327(5968): 1008-1009.

Hawkes G E, Powlson D S, Randall E W, et al. 1984. A ${ }^{31} \mathrm{P}$ nuclear magnetic resonance study of the phosphorus species in alkali extracts of soils from long-term field experiments. Journal of Soil Science, 35: 35-45.

Hogan E J, Minnullina G, Smith R I, et al. 2010. Effects of nitrogen enrichment on phosphatase activity and nitrogen: phosphorus relationships in Cladonia portentosa. New Phytologist, 186(4): 911-925.

Intergovernmental Panel on Climate Change (IPCC). 2007. IPCC WGI Fourth Assessment Report to Climate Change: The Physical Science Basis. Geneva: IPCC Secretariat.

Johnson D, Leake J R, Lee J A, et al. 1998. Changes in soil microbial biomass and microbial activities in response to 7 years simulated pollutant nitrogen deposition on a heathland and two grasslands. Environmental Pollution, 103(2-3): 239-250.

Jouany C, Cruz P, Daufresne T, et al. 2011. Biological Phosphorus Cycling in Grasslands: Interactions with Nitrogen. In: Bünemann E, Oberson A, Frossard E. Phosphorus in Action. Verlag Berlin Heidelberg: Springer, 275-294.

Kirschbaum M U F. 2000. Will changes in soil organic carbon act as a positive or negative feedback on global warming? Biogeochemistry, 48(1): 21-51.

Kuo S. 1996. Phosphorus. In: Sparks D, Page A, Helmke P, et al. Methods of Soil Analysis: Part 3, Chemical Methods. Madison: Soil Science Society of America, 869-920.

Li L J, Zeng D H, Yu Z Y, et al. 2010. Soil microbial properties under N 
and $\mathrm{P}$ additions in a semi-arid, sandy grassland. Biology and Fertility of Soils, 46(6): 653-658.

Limpens J, Berendse F, Klees H. 2004. How phosphorus availability affects the impact of nitrogen deposition on sphagnum and vascular plants in bogs. Ecosystems, 7(8): 793-804.

Malhi S S, Nyborg M, Goddard T, et al. 2011. Long-term tillage, straw and $\mathrm{N}$ rate effects on some chemical properties in two contrasting soil types in Western Canada. Nutrient Cycling in Agroecosystems, 90(1): 133-146.

McDowell R W, Condron L M, Stewart I, et al. 2005. Chemical nature and diversity of phosphorus in New Zealand pasture soils using P-31 nuclear magnetic resonance spectroscopy and sequential fractionation. Nutrient Cycling in Agroecosystems, 72(3): 241-254.

McGill W B, Cole C V. 1981. Comparative aspects of cycling of organic C, N, S and P through soil organic matter. Geoderma, 26(4): 267-286.

Murphy J, Riley J P. 1962. A modified single solution method for the determination of phosphate in natural waters. Analytica Chimica Acta, 27: 31-36.

Murphy P N C, Bell A, Turner B L. 2009. Phosphorus speciation in temperate basaltic grassland soils by solution P-31 NMR spectroscopy. European Journal of Soil Science, 60(4): 638-651.

Niu S L, Wan S Q. 2008. Warming changes plant competitive hierarchy in a temperate steppe in Northern China. Journal of Plant Ecology, 1(2): 103-110.

Nyborg M, Malhi S S, Solberg E D, et al. 1999. Carbon storage and light fraction $\mathrm{C}$ in a grassland Dark Gray Chernozem soil as influenced by $\mathrm{N}$ and $\mathrm{S}$ fertilization. Canadian Journal of Soil Science, 79(2): 317-320.

Olsen S R, Cole C V, Watanabe F S, et al. 1954. Estimation of available phosphorus in soils by extraction with sodium bicarbonate. USDA Circular, 939: 1-19.

Sumann M, Amelung W, Haumaier L, et al. 1998. Climatic effects on soil organic phosphorus in the North American Great Plains identified by phosphorus-31 nuclear magnetic resonance. Soil Science Society of America Journal, 62(6): 1580-1586.

Tiemann L K, Billings S A. 2011. Indirect effects of nitrogen amendments on organic substrate quality increase enzymatic activity driving decomposition in a mesic grassland. Ecosystems, 14: 234-247.

Turner B L, Haygarth P M. 2001. Biogeochemistry: phosphorus solubilization in rewetted soils. Nature, 411: 258.
Turner B L, Chudek J A, Whitton B A, et al. 2003a. Phosphorus composition of upland soils polluted by long-term atmospheric nitrogen deposition. Biogeochemistry, 65(2): 259-274.

Turner B L, Mahieu N, Condron L M. 2003b. The phosphorus composition of temperate pasture soils determined by $\mathrm{NaOH}-\mathrm{EDTA}$ extraction and solution P-31 NMR spectroscopy. Organic Geochemistry, 34(8): 1199-1210.

Turner B L, Mahieu N, Condron L M. 2003c. Phosphorus-31 nuclear magnetic resonance spectral assignments of phosphorus compounds in soil NaOH-EDTA extracts. Soil Science Society of America Journal, 67(2): 497-510.

Turner B L, Cade-Menun B J, Westermann D T. 2003d. Organic phosphorus composition and potential bioavailability in semi-arid arable soils of the western United States. Soil Science Society of America Journal, 67(4): 1168-1179.

Turner B L, Baxter R, Mahieu N, et al. 2004. Phosphorus compounds in subarctic Fennoscandian soils at the mountain birch (Betula pubescens)-tundra ecotone. Soil Biology \& Biochemistry, 36(5): $815-823$.

Turner B L. 2007. Inositol phosphates in soil: amounts, forms and significance of the phosphorylated inositol stereoisomers. In: Turner B L, Richardson A E, Mullaney E J. Inositol Phosphates: Linking Agriculture and the Environment. Wallingford, UK: CAB International, 186-206.

Turner B L, Romero T E. 2010. Stability of hydrolytic enzyme activity and microbial phosphorus during storage of tropical rain forest soils. Soil Biology \& Biochemistry, 42(3): 459-465.

Turner B L, Engelbrecht B M J. 2011. Soil organic phosphorus in lowland tropical rain forests. Biogeochemistry, 103: 297-315.

Xia J Y, Niu S L, Wan S Q. 2009. Response of ecosystem carbon exchange to warming and nitrogen addition during two hydrologically contrasting growing seasons in a temperate steppe. Global Change Biology, 15(6): 1544-1556.

Zhang A M, Chen Z H, Zhang G N, et al. 2012. Soil phosphorus composition determined by ${ }^{31} \mathrm{P}$ NMR spectroscopy and relative phosphatase activities influenced by land use. European Journal of Soil Biology, 52(7): 73-77.

Zhang Y G, Xu Z W, Jiang D M. et al. 2013. Soil exchangeable base cations along a chronosequence of Caragana microphylla plantation in a semi-arid sandy land, China. Journal of Arid Land, 5(1): 42-50. 